\title{
Extraction of Squid (Photololigo Duvaucelii) Myofibrillar and Sarcoplasmic Proteins to Create A Skin Prick Test Reagent In The Diagnosis of Food Allergy
}

\author{
Hendra Wijaya ${ }^{1}$, Fransiska Rungkat Zakaria ${ }^{2}$, Dahrul Syah ${ }^{2}$, Endang \\ Prangdimurti ${ }^{2}$ \\ 1) Center for Agro-based Industry, Ministry of Industry, Jln. Ir. H. Juanda No. 11, Bogor-16122, Indonesia \\ ${ }^{2)}$ Department of Food Science and Technology, Faculty of Agricultural Engineering, Bogor Agricultural \\ University, IPB Darmaga Campus, Bogor-16680, Indonesia
}

\begin{abstract}
The major and minor allergens in fish and shellfish that have been identified are broadly spread in the myofibrillar and sarcoplasmic proteins. This study aimed to create the SPT reagents of squid myofibrillar and sarcoplasmic proteins to improve sensitivity and specificity diagnosis. Myofibrillar protein fraction was composed of 11 protein bands with the molecular weights of 18.2-108.4 kDa and sarcoplasmic protein fraction was composed of 13 protein bands with the molecular weights of 9.5-119.3 kDa. The allergenic myofibrillar protein has the molecular weights of 8.9-122.7 kDa while the allergenic sarcoplasmic protein has the molecular weights of 11.8-143.9 kDa. Each allergen extract was formulated into a SPT reagent met the requirements of the European Pharmacopoeia Monograph on Allergen Products 7 (2010:1063) for the parameters of moisture content, protein content, sterility and microbiology. A SPT to the respondents indicated that the sensitivity value of squid myofibrillar reagent was $86 \%$ and squid sarcoplasmic reagent was $64 \%$ with a negative error rate for each myofibrillar and sarcoplasmic reagents was $14 \%$ and $36 \%$, respectively. The result diagnosis of squid myofibrillar and sarcoplasmic would generate sensitivity value at 100\%. The separation of squid proteins into myofibrils and sarcoplasm for SPT could improve its sensitivity value and lowered the negative misdiagnosis. The specificity of each myofibrillar and sarcoplasmic proteins was 100\% with an error rate of positive diagnosis occurrence at $0 \%$.
\end{abstract}

Keywords - allergy diagnosis, myofibrillar, sarcoplasmic, squid, skin prick test.

\section{INTRODUCTION}

Indonesia's squid (Photololigo duvaucelii) production volume in 2012 was 140.924 tonnes and has increased by $18.83 \%$ since 2007 [1]. Indonesian people's consumption level for fishery products, including squid, also increased by $5.21 \%$ in 2007 to 2012 . This increased consumption is due to squid's nutrient content and preferred taste. In some people, squid consumption can cause type 1 allergic reaction (hypersensitivity) mediated by IgE antibodies and can be fatal. Allergic reaction is mainly triggered by allergen content in the squid. Squid is one of the top seven major causes of allergic reaction in the world [2]. The incidence of allergies from consuming squid in Indonesia is high, especially in adults.

Skin prick test (SPT) is a reliable method for diagnosing allergies that are mediated by $\operatorname{IgE}$ antibodies in patients with rhinocon-junctivitis, asthma, urticaria, anapylaxis, atopic eczema, drug and food allergies [3]. SPT method was first published by Helmtraud Ebruster in 1959 and has been used as a primary diagnostic method for detection of type I hypersensitivity reactions [4]. The main material used for the SPT is allergen extract or SPT reagent. Allergen extract is a mixture of a variety of different proteins, glycoproteins and polysaccharides. Allergen extract should contain major and minor allergens because not all patients are allergic to any antigen in the extract. Each manufacturer produces different quality and specifications of SPT reagent, although derived from the same allergen. This matter will cause different SPT results although derived from the same allergens but produced by different manufacturers [3]. The variations of SPT reagent quality caused by differences in the raw materials used, extraction methods, and formulation during the manufacture of SPT reagent [5]. Raw material factors that could affect the quality of SPT reagent are the origin of raw materials, varieties, transportation, food processing, and changes during storage [6]. The same species but derived from different regions have different allergen compositions and also different IgE reactivity [7]. Extraction method that is widely used for animal products such as eggs and marine products are generally using PBS solution. An isolation of snow crab meat protein using PBS solution $(\mathrm{pH} 7.2,0.01 \mathrm{~mol} / \mathrm{L})[8]$. 
The major and minor allergens in fish and shellfish that have been identified are broadly spread in the myofibrillar and sarcoplasmic proteins. The examples are allergens in the north sea shrimp (Crangon Crangon). Based on Allergen Nomenclature, allergens in the north sea shrimp (Crangon Crangon) can be grouped into myofibrilllar and sarcoplasmic proteins. Allergens in myofibrilllar group are Cra c 1 (MW $38 \mathrm{kDa})$, Cra c 5 (MW $17.5 \mathrm{kDa})$, Cra c 6 (MW $21 \mathrm{kDa})$ Cra c 8 (MW $28 \mathrm{kDa}$ ) whereas allergens in sarcoplasmic group are Cra c $2(45 \mathrm{kDa})$ and Cra c $4(25 \mathrm{kDa})$ [9]. This study aimed to create the SPT reagents with separating myofibrillar and sarcoplasmic proteins to be expected to improve the sensitivity and selectivity of the diagnosis, thereby reducing the misdiagnosis occurrence. The quality requirements of SPT reagent referred to European Pharmacopoeia 7 Monograph on Allergen Products (2010:1063) standard [10].

\subsection{Materials}

\section{MATERIALS AND METHODS}

The main material used in this study was fresh squids (Photololigo duvaucelii) obtained from the Muara Angke fish market, North Jakarta. The main chemicals used were BSA (bovine serum albumin), acrylamide, glycine, 2-Mercaptoethanol, $0.05 \mathrm{M}$ carbonate-bicarbonate buffer at pH 9.6. coomasie brilliant blue R-250, coomasie brilliant blue G-250, IgE antibody, anti-IgE human antibody labeled with HRP (Horseradish Peroxidase) enzyme, DAB (3,3'-Diaminobenzidine) substrate, TMB (3,3',5,5'-Tetramethylbenzidine) substrate, N,N'-methylenebisacrylamide, low molecular weight proteins (LMW) Fermentas ${ }^{\circledR}$ (containing 7 types of protein, which are $\beta$-galactosidase standards (MW: $116 \mathrm{kDa}$ ), bovine serum albumin (MW: 66.2 kDa), ovalbumin (MW: $45 \mathrm{kDa}$ ), lactase dehydrogenase (MW: $35 \mathrm{kDa}$ ), REase BSP 981 (MW: $25 \mathrm{kDa}), \beta$ lactoglobulin (MW: $18.4 \mathrm{kDa})$, and lysozyme (MW: $14.4 \mathrm{kDa})$. Other chemicals were purchased from Sigma.

\subsection{Equipments}

The equipments used were high speed microcentrifuge, SDS-PAGE Bio-Rad Mini-Protean II tool, immunoblotting Mini Trans-Blot ${ }^{\circledR}$ Electrophoretic Transfer Cell Bio-Rad tool, Costar ${ }^{\circledR}$ 96-well ELISA microplates, LabSystem Multiskan EX ELISA reader, UV-VIS spectrophotometer, freeze drier, nitrocellulose membranes for blotting pore size $0.45 \mu \mathrm{m}$, size $15 \mathrm{~cm}$ x $15 \mathrm{~cm}$ (Sigma N8267), pH meter, sonicator, vortex mixer, stirrer, $0.5 \mu \mathrm{L}$ to $1000 \mu \mathrm{L}$ micropipettes, $0.2 \mu \mathrm{m}$ SFCA syringe filter, Whatman \#1 filter paper, and other glasswares.

\subsection{Extraction of Squid Myofibrillar dan Sarcoplasmic Proteins}

20 grams of cleaned squid was put into a blender, added with $200 \mathrm{~mL}$ of phosphate buffer (pH 7.5) with ionic strength $(\mathrm{I})=0.05 \mathrm{M}\left(15,6 \mathrm{mM} \mathrm{Na} \mathrm{HPO}_{4}, 3.5 \mathrm{mM} \mathrm{KH}_{2} \mathrm{PO}_{4}\right)$ then added with $0.5 \mathrm{~mL}$ aprotinin (protease inhibitor) and homogenized $3 \mathrm{x} @ 1$ minute. The formed mixture was centrifuged at $4{ }^{\circ} \mathrm{C}$ with $5000 \times \mathrm{g}$ speed for $25 \mathrm{~min}$. The centrifuge result consisted of liquid at the top layer (supernatant) and pellet (solid) at the bottom layer. The supernatant was collected in a $50 \mathrm{~mL}$ centrifuge tube and the pellets remained in a centrifuge tube were re-added with $200 \mathrm{~mL}$ of phosphate buffer $(\mathrm{pH} 7.5, \mathrm{I}=0.05 \mathrm{M}$ ) to be re-extracted. The supernatant was then combined in a $50 \mathrm{~mL}$ centrifuge tube (hereinafter called the sarcoplasmic protein fraction), while the pellets were further processed for myofibrillar protein extraction. The pellets were added with $200 \mathrm{~mL}$ of phosphate buffer $\left(\mathrm{pH} 7.5, \mathrm{I}=0.5 \mathrm{M} ; 0.45 \mathrm{M} \mathrm{KCl}, 15.6 \mathrm{mM} \mathrm{Na} \mathrm{HPO}_{4}, 3.5 \mathrm{mM} \mathrm{KH} \mathrm{PO}_{4}\right)$ and homogenized $3 \mathrm{x}$ @ 1 minute. The formed mixture was centrifuged at $4{ }^{\circ} \mathrm{C}$ with $5000 \times \mathrm{g}$ speed for $25 \mathrm{~min}$. The obtained supernatant was the myofibrillar protein extracts and the obtained pellets were re-extracted [11].

\subsection{Serum Preparation}

Serum collection was conducted in two steps. The first step was conducted toward 25 respondents who have food allergy (discovered from interviews). This serum was later used to conduct the allergenicity test of squid myofibrillar and sarcoplasmic proteins using ELISA and immunoblotting methods prior to the SPT. The second step of serum collection was conducted toward 12 respondents with squid allergy and 12 respondents without squid allergy which later used to conduct allergenicity test of SPT reagent. Second-step respondents attended SPT in allergy clinic. Serum collection and SPT were conducted by medical personnel and allergologist physician who have obtained permission from the Health Research Ethics Committee, Faculty of Medicine Indonesia University, Cipto Mangunkusumo Hospital with number of ethical approval is 199/H2.F1/ETIK/2014. $10 \mathrm{~mL}$ of each respondent's blood was withdrawn then placed in a bottle containing no EDTA. The withdrawn blood was allowed to stand for 1 hour, then centrifuged for 20 minutes at $2500 \mathrm{rpm}$ $(1250 \mathrm{~g})$. The obtained supernatant was a serum containing $\mathrm{IgE}$ antibodies and stored at $-20^{\circ} \mathrm{C}$ [12]. 


\subsection{SDS-PAGE Electrophoresis and Immunoblotting}

Electrophoresis was conducted according to Laemmli [13] with $12 \%$ concentration of separating gel and stained with coomasie brilliant blue R-250. The unstained gel from electrophoresis result was transferred to $0,45 \mu \mathrm{m}$ nitrocellulose membrane using transblotting equipment with $90 \mathrm{~V}$ voltage for 90 minutes. After being transferred, the membrane was removed from equipment and soaked with $50 \%$ methanol for 2 minutes, then blocked with 5\% skim milk in PBST (Phosphate Buffered Saline with $0.05 \%$ Tween $® 20$ ) for 1 hour at room temperature. The membrane was washed with PBST 3 times, each for 5 minutes. After being washed, the membrane was added with the allergic patient serum with 1:10 dilution in PBST, then incubated for 2 hours at room temperature. Washing was conducted again (3 times) with PBST, each for 5 minutes, then added with HRP conjugated monoclonal mouse anti-human IgE antibody (1:3000 dilution in PBST) and incubated for 1 hour while shaken. After that, the membrane was re-washed with PBST (3 times) each for 5 minutes, and added with DAB substrate. Positive detection results were marked with the formation of brown-colored band on nitrocellulose membrane [14].

\subsection{Determination of Total IgE with ELISA Method}

$100 \mu \mathrm{L}$ serum/well with a 1:10 dilution (in $0.05 \mathrm{M}$ carbonate-bicarbonate buffer at $\mathrm{pH}$ 9.6) was attached to the microtiter plates and incubated for 1 night at $4{ }^{\circ} \mathrm{C}$. Normal human sera (NHS) were used as control. The remaining sample was removed and the microtiter plates were washed 5 times with PBST (250 $\mu \mathrm{L} /$ well). After that, $200 \mu \mathrm{L} /$ well of $5 \%$ skim milk in PBST was added and incubated for 1 hour at $37^{\circ} \mathrm{C}$. Furthermore, it was washed 5 times with PBST $(250 \mu \mathrm{L} /$ well $)$ and added with $100 \mu \mathrm{L} /$ well of HRP conjugated monoclonal mouse anti-human IgE antibody (with 1:6000 dilution in PBST), then incubated at $37^{\circ} \mathrm{C}$ for 1 hour. The microtiter plates were washed with PBST ( $250 \mu \mathrm{L} /$ well) for 10 times, then added with $100 \mu \mathrm{L} /$ well of TMB substrate. Positive results were marked when blue color developed. After 5 minutes, the reaction was stopped by adding $100 \mu \mathrm{L} /$ well of $2 \mathrm{M} \mathrm{H}_{2} \mathrm{SO}_{4}$, and the solution would turn bright yellow. Optical density (OD) was measured using ELISA reader at $450 \mathrm{~nm}$. Mean $\pm 2 \mathrm{SD}$ of normal controls was taken as cut-off for ELISA positive results [12]; [15].

\subsection{Determination of Specific IgE with ELISA Method}

$100 \mu \mathrm{L} /$ well of each squid myofibrillar and sarcoplasmic proteins $10 \mu \mathrm{g} / \mathrm{mL}$ (in $0.05 \mathrm{M}$ carbonatebicarbonate buffer, $\mathrm{pH}$ 9.6) was attached to the microtiter plates, then incubated at $4{ }^{\circ} \mathrm{C}$ for 1 night. The remaining sample was removed and the microtiter plates were washed for 5 times with PBST $(250 \mu \mathrm{L} /$ well). After that, $200 \mu \mathrm{L} /$ well of $5 \%$ skim milk in PBST was added and incubated for 1 hour at $37^{\circ} \mathrm{C}$. Furthermore, it was washed 5 times with PBST ( $250 \mu \mathrm{L} /$ well). $100 \mu \mathrm{L} /$ well of allergic patient serum with 1:10 dilution in PBST was added and incubated for 1 hour at $37^{\circ} \mathrm{C}$. Normal human sera (NHS) were used as control. After incubation, the microtiter plates were washed with PBST $(250 \mu \mathrm{L} /$ well) for 5 times, then added $100 \mu \mathrm{L} /$ well of HRP conjugated monoclonal mouse anti-human IgE antibody (diluted 1:6000 in PBST), then incubated for 1 hour at $37^{\circ} \mathrm{C}$. Microtiter plates were washed with PBST $(250 \mu \mathrm{L} /$ well $)$ for 10 times, and $100 \mu \mathrm{L} /$ well of TMB substrate was added. Positive results were marked when blue color developed. After 5 minutes, the reaction was stopped by adding $100 \mu \mathrm{L} /$ well of $2 \mathrm{M} \mathrm{H}_{2} \mathrm{SO}_{4}$, and the solution would turn bright yellow. Optical density (OD) was measured using ELISA reader at $450 \mathrm{~nm}$. Mean $\pm 2 \mathrm{SD}$ of normal controls was taken as cut-off for ELISA positive results [12]; [15].

\subsection{Creating Skin Prick Test Reagent}

Each $0.2 \mathrm{~g}$ of myofibrillar and sarcoplasmic proteins isolates was dissolved in $2 \mathrm{~mL}$ of phosphate buffer saline (PBS) at pH 7.4, sonicated $5 \mathrm{x} @ 1$ minute in cold condition and then centrifuged at $11780 \mathrm{~g}$ for 15 minutes. The obtained supernatant was filtered using $0,2 \mu \mathrm{m}$ syringe filter for sterilization in order to obtain a sterile protein stock solution. The procedure was conducted in a sterile and aseptic room. The protein content of stock solution was determined using the Bradford method (Bradford, 1976). Stock solution was then dissolved in $50 \%$ glycerol-saline solution containing $0.4 \%$ sterile phenol, thus the concentration became $1 \mathrm{mg} / \mathrm{mL}$. The obtained solution was then called "squid myofibrillar and sarcoplasmic SPT reagent" which then tested chemically, sterilitically and microbiologically. If it was qualified from chemical, sterility and microbiological tests, the reagent would be used for SPT in humans [16].

\subsection{Skin Prick Test}

The SPT was conducted by allergologist physician who has received permission from the Health Research Ethics Committee with number of ethical approval is 199/H2.F1/ETIK/2014. SPT was conducted on the volar forearm. The area that dropped with reagent was marked with a ballpoint and disinfected with alcohol. $1 \mathrm{mg} / \mathrm{ml}$ histamine was used as a positive control and 50\% glycerol-saline solution was used as a negative 
control. Positive and negative controls were dropped on the opposite area then other reagents were dropped. Skin prick that has been dropped with histamine, control buffer, and allergen extracts using the brown marrow needle. The pricking process was conducted slowly with $45^{\circ}$ slope the penetrated the epidermal layer without causing bleeding. The diameter of the wheal (urtica) on the skin was measured after 15-20 minutes by measuring the developed wheal (urtica). The test results were transferred to the millimeter block paper by making line surrounding the wheal border with marker pen (size 0.2), taped with masking tape and masking tape was affixed to the millimeter paper block. Each circle diameter on the tape was then measured. The result expressed as "0" when the wheal size is equal to the negative control (no wheal formed), "+1" if the wheal size is $25 \%-50 \%$ greater than the negative control $(<3 \mathrm{~mm})$, " +2 " if the wheal size is $50 \%-75 \%$ greater than the negative control $(3 \mathrm{~mm}-5 \mathrm{~mm})$ and " +3 " if the wheal size is equal to the histamine $(5 \mathrm{~mm}-7 \mathrm{~mm})$, and " +4 " if the wheal size is $25 \%-50 \%$ greater than the histamine and " $>+4$ " when the wheal size is more than $50 \%$ greater than the histamine. From the SPT results, sensitivity and selectivity of each reagent were measured [16].

\subsection{Analysis of Total IgE and Specific IgE Antibodies}

\section{RESULTS AND DISCUSSION}

Analysis of total IgE antibodies in the respondents serum aimed to determine the status of the respondent, whether they have positive or negative allergy. The selected respondents must have food allergy history based on the interview results. The analysis result showed that 25 respondents (respondent 1-25) have positive allergy and suitable for allergenicity test. Analysis of specific IgE antibodies aimed to determine the ability of squid myofibrillar and sarcoplasmic proteins to bind with specific IgE antibodies in the serum and also to determine whether the respondents have positive or negative squid allergy. 9 of 25 respondents (36\%) have positive squid allergy and 11 respondents (44\%) were allergic to squid myofibrils.

A person who consumes a squid not only eats myofibrillar protein or sarcoplasmic protein, but consumes both. If the diagnosis results indicate that the person is positively allergic to squid myofibrils and not allergic (negative) to squid sarcoplasm, vice versa, then the allergic status to squid is positive. The analysis results showed that respondents who were allergic to squid was 14 respondents or $56 \%$ of the total respondents. Serum that has a high allergenicity was used to determine the protein allergens profile with immunoblotting.

\subsection{Profiles of Protein and Squid Myofibrillar Allergens}

Fig. 1 shows the profile of squid myofibrillar protein from SDS-Page Electrophoresis results (A) and the profile of protein allergens from immunoblotting with allergic respondents serum (B). The identification results using GelAnalyzer 2010a software showed that squid myofibrillar protein consisted of 11 bands with different intensities. The detected molecular weights of myofibrillar protein were 108,4 kDa, 92,2 kDa, 82,9 $\mathrm{kDa}, 74,1 \mathrm{kDa}, 64,8 \mathrm{kDa}, 58,4 \mathrm{kDa}, 54,8 \mathrm{kDa}, 35,8 \mathrm{kDa}, 32,5 \mathrm{kDa} 22,5 \mathrm{kDa}$ and $18,2 \mathrm{kDa}$. with the greatest intensites were protein with molecular weight of $35.8 \mathrm{kDa}(22.9 \%), 64.8 \mathrm{kDa}$ protein $(18.3 \%)$ and $108.4 \mathrm{kDa}$ protein (13.6\%). According to Ashie and Simpson (1997), the molecular weight of myofibrillar protein ranges from $17 \mathrm{kDa}$ to $1000 \mathrm{kDa}$. $17-18 \mathrm{kDa}$ proteins are suspected as troponin-C, 20-24 $\mathrm{kDa}$ proteins are suspected as troponin-I, while 65-70 $\mathrm{kDa}$ proteins are suspected as tropomyosin.

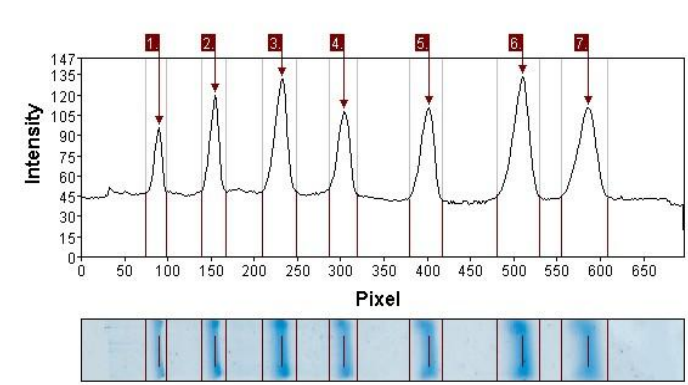

Marker

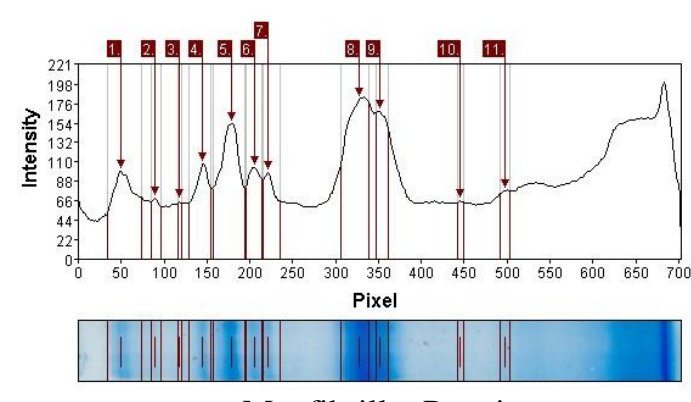

Myofibrillar Protein

A. Electrophoresis results of squid myofibrillar protein 

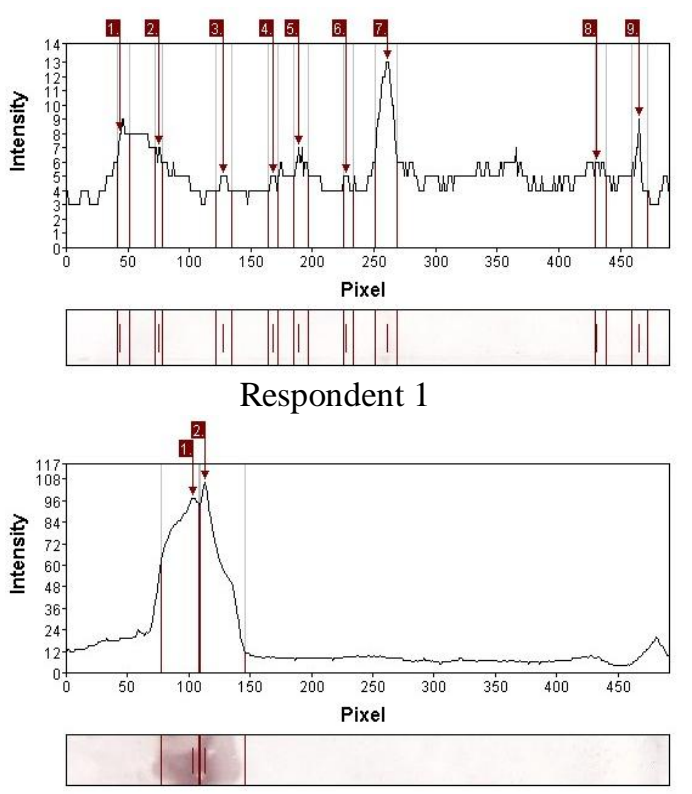

Respondent 15

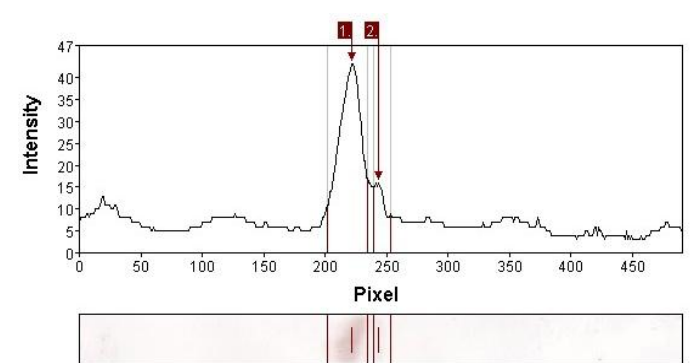

Respondent 12

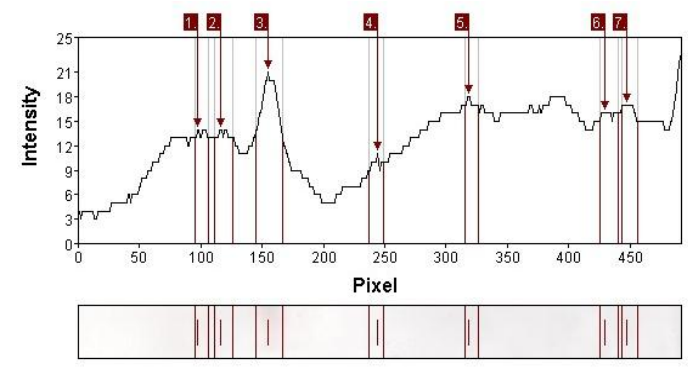

Respondent 20

A. Immunoblotting results of squid myofibrillar protein

Figure 1. SDS-Page Electrophoresis results (A) (marker and squid myofibrils) and immunoblotting (B) (Respondent 1, 12, 15 and 20)

Fig. 1 shows the protein profile of squid myofibrillar allergens that can bind to specific IgE antibodies from 4 serums of squid allergic respondents. The serum of allergic patients was selected with a high allergenicity level of squid myofibrils that has been determined by ELISA method. Protein allergens that could bind to the specific IgE antibodies in 1, 12, 15, and 20 respondent serums were 9 bands, 2 bands, 2 bands and 7 bands, respectively. Squid myofibrillar protein allergens that could bind to serum 1 specific IgE were 122,7 $\mathrm{kDa}, 100,6 \mathrm{kDa}, 72,7 \mathrm{kDa}, 56,4 \mathrm{kDa}, 49,4 \mathrm{kDa}, 38,6,0 \mathrm{kDa}, 31,5 \mathrm{kDa}, 10,9 \mathrm{kDa}$, and 8,9 kDa. Specific IgE antibodies in serum 12 that could bind to squid myofibrillar protein were $40.0 \mathrm{kDa}$ and $35.9 \mathrm{kDa}$, whereas in respondent serum 15 were $83.9 \mathrm{kDa}$ and $78.7 \mathrm{kDa}$ and in respondent 20 were 87,6 kDa, 77,8 kDa, 61,0 kDa, $35,1 \mathrm{kDa}, 22,1 \mathrm{kDa}, 11,0 \mathrm{kDa}$, and 9,9 kDa. The $38.6 \mathrm{kDa}$ protein which was detected using serum 1 was suspected as a major allergen contained in the squid, namely tropomyosin proteins (Tod p 1) according to Allergen Nomenclature ([9]; [17]; [18]). Other major allergen found in squid is tropomyosin protein with the molecular weight of $36 \mathrm{kDa}$ and the one that could be detected using serum 12 has $35.9 \mathrm{kDa}$ molecular weight [19].

\subsection{The Profiles of Squid Sarcoplasmic Protein and Allergen}

The number of detected sarcoplasmic proteins were more than myofibrillar proteins. The detected sarcoplasmic proteins were $119,3 \mathrm{kDa}, 105,4 \mathrm{kDa}, 97,2 \mathrm{kDa}, 88,1 \mathrm{kDa}, 82,2 \mathrm{kDa}, 77,3 \mathrm{kDa}, 69,1 \mathrm{kDa}, 59,6$ $\mathrm{kDa}, 54,4 \mathrm{kDa}, 42,6 \mathrm{kDa}, 32,2 \mathrm{kDa}, 17,1 \mathrm{kDa}$, and 9,5 kDa with the greatest intensities were $42.6 \mathrm{kDa}$ protein $(19.2 \%), 32.2 \mathrm{kDa}$ protein $(18.5 \%)$ and $9.5 \mathrm{kDa}$ protein $(13 \%)$, respectively.

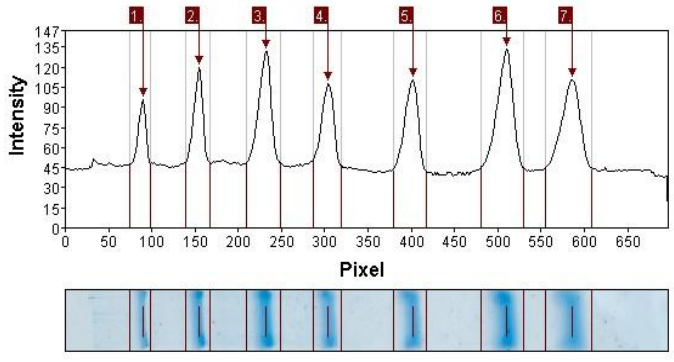

Marker

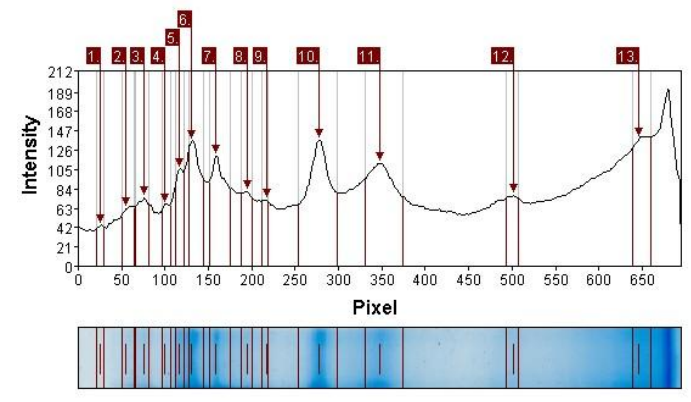

Sarcoplasmic protein

(A) SDS-PAGE Electrophoresis results of squid sarcoplasmic protein 


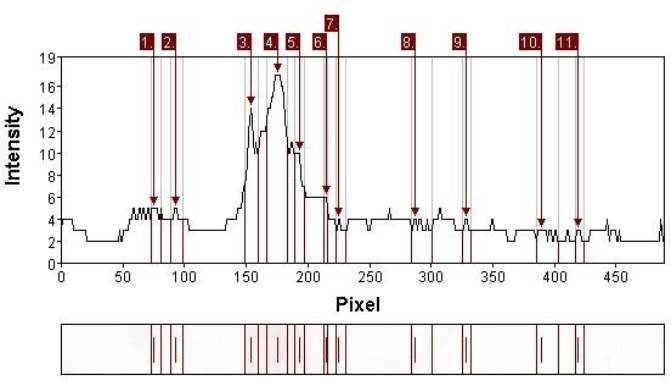

Respondent 4

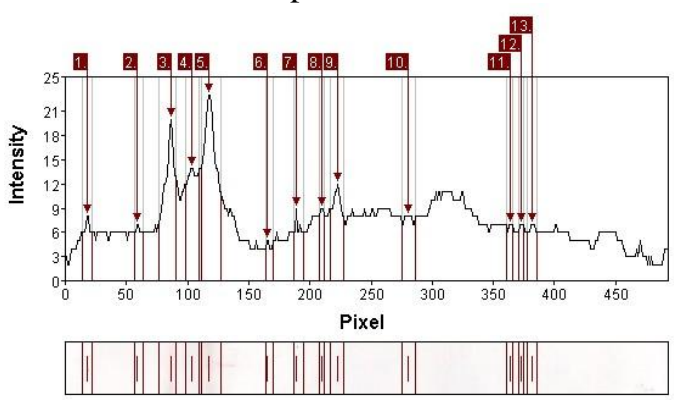

Respondent 12

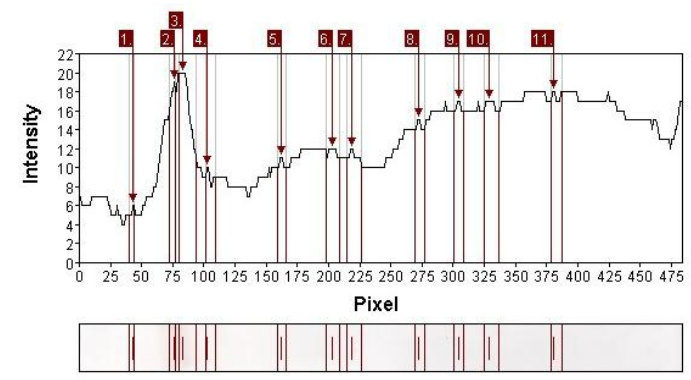

Respondent 5

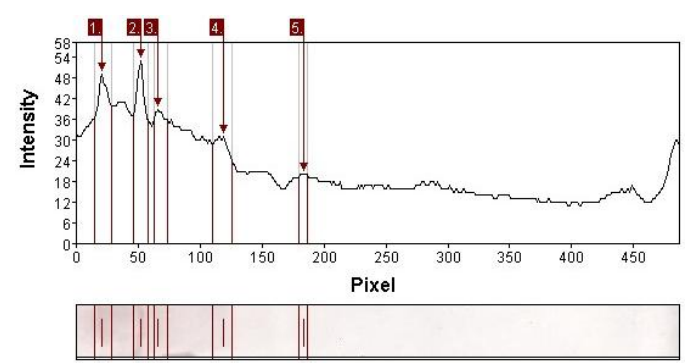

Respondent 23

(B) Immunoblotting results of squid myofibrillar protein

Figure 2. SDS-PAGE Electrophoresis results (A) (marker and squid sarcoplasm) and immunoblotting (B)

(Respondent 4, 5, 12 and 23)

Fig. 2 shows the protein could bind to the specific IgE each in 4, 5, 12 and 23 respondents were 11 bands, 11 bands, 13 bands and 5 bands, respectively. Sarcoplasmic proteins that could bind to specific IgE antibodies in serum 4 were 100,6 kDa, 89,8 kDa, 61,4 kDa, 53,8 kDa, 48,2 kDa, 42,0 kDa, 39,5 kDa, 26,9 kDa, $20,8 \mathrm{kDa}, 14,2 \mathrm{kDa}$, and 11,8 kDa protein while in serum 5 were 122,7 kDa, 99,7 kDa, 95,5 kDa, 85,0 kDa, 58,5 $\mathrm{kDa}, 45,2 \mathrm{kDa}, 42,3 \mathrm{kDa}, 29,4 \mathrm{kDa}, 24,1 \mathrm{kDa}, 20,6 \mathrm{kDa}$, and 15,0 kDa proteins. Sarcoplasmic proteins that could bind to specific IgE antibodies in serum 12 were 143,9 kDa, 111,6 kDa, 94,3 kDa, 85,0 kDa, 77,8 kDa, $57,8 \mathrm{kDa}, 49,7 \mathrm{kDa}, 42,8 \mathrm{kDa}, 40,2 \mathrm{kDa}, 28,2 \mathrm{kDa}, 16,7 \mathrm{kDa}, 15,8 \mathrm{kDa}$, and 15,0 kDa protein, while in serum 23 were 140,4 kDa, 115,8 kDa, 106,3 kDa, 76,3 kDa, and 51,0 kDa protein.

Several seafood sarcoplasmic proteins which can cause allergens is the sarcoplasmic calcium binding protein with $20 \mathrm{kDa}$ molecular weight [20], hemocyanin with $72 \mathrm{kDa}$ molecular weight [21], arginine kinase with $42 \mathrm{kDa}$ molecular weight [22] and amylase [23]. Protein with a molecular weight of $42 \mathrm{kDa}$ is suspected as arginine kinase that can bind to specific IgE antibodies in 4, 5 and 12 serums. Protein with $20 \mathrm{kDa}$ molecular weight is suspected as sarcoplasmic calcium binding protein that can bind to specific IgE antibodies in serum 5 .

\subsection{Formulation and Quality Requirements of Allergen Products for SPT}

Allergen products or reagent made in this study was a product of glycerinated extract containing $50 \%$ glycerol. Table 1 shows the requirements from European Pharmacopoeia 7 Monograph on Allergen Product (2010:1063) and the analysis results of allergen products of squid myofibrils and sarcoplasm. The analysis results showed that allergen products of squid myofibrils and sarcoplasm used for the diagnosis of squid allergy with SPT method have met the requirements set by the European Pharmacopoeia 7 Monograph on Allergen Products (2010:1063).

Table 1. Requirements of European Pharmacopoeia 7 Monograph on Allergen Product (2010: 1063) and the analysis results of allergen products of squid myofibrils and sarcoplasm

\begin{tabular}{clccc}
\hline No. & \multicolumn{2}{c}{ European Pharmacopoeia 7} & \multicolumn{2}{c}{ Analysis Results } \\
\cline { 2 - 5 } Parameters & \multicolumn{1}{c}{ Requirements } & Myofibrils & Sarcoplasm \\
\hline & $\begin{array}{l}\text { Moisture } \\
(\%)\end{array}$ & $\begin{array}{c}\text { Maximum 5\% for freeze-dried } \\
\text { products and can be more than } \\
5 \% \text { for liquid products }\end{array}$ & $\begin{array}{c}60,20 \pm 0,35 \\
\text { (liquid products) }\end{array}$ & $\begin{array}{c}63,50 \pm 0,06 \\
\text { (liquid products) }\end{array}$ \\
\hline 2 & $\begin{array}{l}\text { Protein content } \\
(\mu \mathrm{g} / \mu \mathrm{l})\end{array}$ & $\begin{array}{l}80-120 \% \text { from the stated } \\
\text { concentration }(1 \mu \mathrm{g} / \mu \mathrm{l})\end{array}$ & 0,86 & 0,90 \\
\hline 3 & Sterility & Sterile, if it is not sterile then & Sterile & Sterile \\
\hline
\end{tabular}




\begin{tabular}{|c|c|c|c|c|}
\hline & & $\begin{array}{c}\text { refers to chapter 5.1.4. on } \\
\text { European Pharmacopoeia } 7 \\
\text { 01/2011:50104 }\end{array}$ & & \\
\hline 4 & Total plate count* & Max $10^{2} \mathrm{CFU} / \mathrm{g}$ or $\mathrm{CFU} / \mathrm{mL}$ & $0,00 \pm 0,00$ & $0,00 \pm 0,00$ \\
\hline 5 & $\begin{array}{l}\text { Staphylococcus } \\
\text { aureus* }\end{array}$ & Not detected in $1 \mathrm{~g}$ or $1 \mathrm{~mL}$ & $0,00 \pm 0,00$ & $0,00 \pm 0,00$ \\
\hline 6 & $\begin{array}{l}\text { Pseudomonas } \\
\text { aeruginosa* }\end{array}$ & Not detected in $1 \mathrm{~g}$ or $1 \mathrm{~mL}$ & $0,00 \pm 0,00$ & $0,00 \pm 0,00$ \\
\hline 7 & Fungi* & \multirow{2}{*}{ Max $10^{1} \mathrm{CFU} / \mathrm{g}$ or $\mathrm{CFU} / \mathrm{mL}$} & $0,00 \pm 0,00$ & $0,00 \pm 0,00$ \\
\hline 8 & Yeast* & & $0,00 \pm 0,00$ & $0,00 \pm 0,00$ \\
\hline
\end{tabular}

\subsection{Skin Prick Test Results}

Table 2 shows that 14 test respondents were allergic patients based on total IgE test results by ELISA method. Analysis of specific IgE of squid myofibrils showed that 13 respondents gave positive allergic results to squid myofibrils and 6 respondents gave positive allergic results to squid sarcoplasm. Overall, all respondents were positively allergic to squid. The results of SPT in Table 2 shows that there is a variation in the results between the myofibrillar protein and sarcoplasmic protein. For example, respondent code 4 showed negative result toward myofibrillar protein (0) but showed very strong positive allergic result $(+4)$ toward sarcoplasmic protein. Contrarily, respondent code 11 gave positive result toward myofibrillar protein $(+2)$ but gave negative result to sarcoplasmic protein (0). There were 7 respondents $(50 \%)$ who showed positive allergic results to the myofibrillar protein and sarcoplasmic protein. Based on the SPT, all respondents in Table 2 are positively allergic to squid although some of them showed negative results on myofibrillar and sarcoplasmic proteins.

Table 2. Total IgE (tIgE), specific IgE (sIgE) and skin prick test result of squid myofibrils and sarcoplasm on the respondents with squid allergy

\begin{tabular}{|c|c|c|c|c|c|c|c|c|}
\hline \multirow[b]{2}{*}{ No } & \multirow{2}{*}{$\begin{array}{l}\text { Resp. } \\
\text { Code }\end{array}$} & \multirow{2}{*}{$\begin{array}{l}\text { tIgE } \\
\text { Result }\end{array}$} & \multicolumn{3}{|c|}{ sIgE result } & \multicolumn{3}{|c|}{ SPT Result } \\
\hline & & & Myofibrils & Sarcoplasm & $\begin{array}{c}\text { Diagnosis } \\
\text { result }\end{array}$ & Myofibrils & Sarcoplasm & $\begin{array}{c}\text { Diagnosis } \\
\text { result }\end{array}$ \\
\hline 1 & 1 & + & + & + & + & 0 & +1 & + \\
\hline 2 & 2 & + & + & - & + & +1 & 0 & + \\
\hline 3 & 3 & + & + & + & + & +3 & +3 & + \\
\hline 4 & 4 & + & - & + & + & 0 & +4 & + \\
\hline 5 & 5 & + & + & - & + & +1 & 0 & + \\
\hline 6 & 11 & + & + & - & + & +2 & 0 & + \\
\hline 7 & 12 & + & + & + & + & +1 & +1 & + \\
\hline 8 & 14 & + & + & - & + & +1 & +2 & + \\
\hline 9 & 17 & + & + & - & + & +1 & 0 & + \\
\hline 10 & 19 & + & + & + & + & +1 & +4 & + \\
\hline 11 & 21 & + & + & - & + & +1 & 0 & + \\
\hline 12 & 22 & + & + & + & + & +3 & +3 & + \\
\hline 13 & 30 & + & + & - & + & +3 & +3 & + \\
\hline 14 & 31 & + & + & - & + & +4 & +3 & + \\
\hline
\end{tabular}

+: Positive, - and 0: Negative, Resp. code: respondent code

Table 3. Total IgE (tIgE), specific IgE (sIgE) and skin prick test result of squid myofibrils and sarcoplasm on the respondents without squid allergy

\begin{tabular}{|c|c|c|c|c|c|c|c|c|}
\hline \multirow[b]{2}{*}{ No } & \multirow{2}{*}{$\begin{array}{l}\text { Resp. } \\
\text { Code }\end{array}$} & \multirow{2}{*}{$\begin{array}{c}\text { tIgE } \\
\text { Result }\end{array}$} & \multicolumn{3}{|c|}{ sIgE Result } & \multicolumn{3}{|c|}{ SPT Result } \\
\hline & & & Myofibrils & Sarcoplasm & $\begin{array}{c}\text { Diagnosis } \\
\text { result }\end{array}$ & Myofibrils & Sarcoplasm & $\begin{array}{c}\text { Diagnosis } \\
\text { result }\end{array}$ \\
\hline 1 & 8 & + & - & - & - & 0 & 0 & - \\
\hline
\end{tabular}




\begin{tabular}{lllllllll}
\hline 2 & 15 & + & - & - & - & 0 & 0 & - \\
3 & 16 & + & - & - & - & 0 & 0 & - \\
4 & 18 & + & - & - & - & 0 & 0 & - \\
5 & 20 & - & - & - & - & 0 & 0 & - \\
6 & 24 & + & - & - & - & 0 & 0 & - \\
7 & 25 & - & - & - & - & 0 & 0 & - \\
8 & 26 & - & - & - & - & 0 & 0 & - \\
9 & 27 & - & - & - & - & 0 & 0 & - \\
10 & 29 & - & - & - & - & 0 & 0 & - \\
11 & 34 & + & - & - & - & 0 & 0 & - \\
12 & 35 & + & - & - & - & 0 & 0 & - \\
\hline
\end{tabular}

+: Positive, - and 0: Negative, Resp. code: respondent code

Table 3 shows that the SPT results of all respondents who were not allergic to the proteins of myofibrillar and sarcoplasmic proteins is negative. It is shown that although based on total IgE the respondents have allergy, but it is not necessarily allergic to squid. Specific IgE results of squid myofibrils and sarcoplasm by ELISA method and SPT indicates that the respondents were not allergic to squid.

Table 4. Sensitivity and specificity of squid reagents for skin prick test

\begin{tabular}{cccccc}
\hline No & SPT Reagent & $\begin{array}{c}\text { Allergy, } \\
\text { Positive SPT, } \\
\text { Sum (\% } \\
\text { Sensitivity) }\end{array}$ & $\begin{array}{c}\text { Allergy, Negative } \\
\text { SPT, Sum (\% } \\
\text { Negative Error) }\end{array}$ & $\begin{array}{c}\text { Non-allergy, Positive } \\
\text { SPT, Sum }(\% \\
\text { Positive Error) }\end{array}$ & $\begin{array}{c}\text { Non-allergy, } \\
\text { Negative SPT, } \\
\text { Sum (\% } \\
\text { Specificity) }\end{array}$ \\
\hline 1 & Myofibrils & $12 / 14(86)$ & $2 / 14(14)$ & $0 / 12(0)$ & $12 / 12(100)$ \\
2 & Sarcoplasm & $9 / 14(64)$ & $5 / 14(36)$ & $0 / 12(0)$ & $12 / 12(100)$ \\
& Diagnosis result & $14 / 14(100)$ & $0 / 14(0)$ & $0 / 12(0)$ & $12 / 12(100)$ \\
\hline
\end{tabular}

Table 4 shows the sensitivity and specificity of squid reagent for SPT test which is measured based on the SPT results in Table 2 and 3. The sensitivity results showed that squid myofibrillar reagent (86\%) was higher than squid sarcoplasmic reagent (64\%) and the error rates for myofibrillar and sarcoplasmic reagents were $14 \%$ and $36 \%$, respectively. If the the sensitivity results of squid myofibrils and sarcoplasm are combined, then the sensitivity value of squid protein isolate is $100 \%$. It can be concluded that the separation of squid proteins into myofibrils and sarcoplasm for SPT test could increase the sensitivity value and decrease the negative diagnosis error. The specificity value of myofibrillar and sarcoplasmic proteins was similar, each one was $100 \%$ with the error rate of positive diagnosis occurence at $0 \%$.

\section{CONCLUSION}

Squid myofibrillar and sarcoplasmic proteins extracts may be used to create SPT reagent in accordance to the requirements of European Pharmacopoeia 7 Monograph on Allergen Products (2010:1063). The separation of squid proteins into myofibrils and sarcoplasm for SPT reagents could improve its sensitivity and specificity value and lowered the negative and positive misdiagnosis. For the purpose of allergy testing practicality in the hospital or allergy clinic, research to calculate the sensitivity and specificity of combined myofibrillar and sarcoplasmic proteins need to be conducted.

\section{REFERENCES}

[1] Direktorat Jenderal Perikanan Tangkap, Capture fisheries statistics of indonesia 2007-2012 (Jakarta: Direktorat Jenderal Perikanan Tangkap, 2013).

[2] R. Pawankar, G.W. Canonica, S.T. Holgate, R.F. Lockey, White Book on Allergy (United Kingdom: World Allergy Organization (WAO), 2011).

[3] L. Heinzerling, A. Mari, K.C. Bergmann, M. Bresciani, G. Burbach, U. Darsow, S. Durham, W. Fokkens, M. Gjomarkaj, T. Haahtela, A.T. Bom, S. Wöhrl, H. Maibach, R. Lockey. The skin prick testEuropean standards, Clin Trans Allergy, 3(3), 2013, 1-10. 
[4] H. Ebruster. The prick test, a recent cutaneous test for the diagnosis of allergic disorders, Wiener klinische Wochenschrift, 71, 1959, 551-554.

[5] K.Y. Jeong, C.S. Hong, J.S. Lee, J.W. Park. Optimization of allergen standardization, Yonsei Med J, 52(3), 2011, 393-400.

[6] R. Esch, T. Grier. Allergen compatibilities in extract mixtures, Immunol Allergy Clin North Am, 31, 2011, 227-239.

[7] K. Milovanović, L. Burazerć. Isolation and characterization of the $68 \mathrm{kD}$ allergen from house dust mite Dermatophagoides pteronyssinus, J Serb Chem Soc, 74(5), 2009, 513-522.

[8] D. Gautrin, B. Neis, B.V. Gill, T.R. Rice. Identification of crab proteins that elicit IgE reactivity in snow crab - processing workers, J Allergy Clin Immunol 124, 2009, 1055-1061.

[9] World Health Organization and International Union of Immunological Societies Allergen Nomenclature Sub-committee (WHO/IUIS), Allergen $\quad$ Nomenclature, http://www.allergen.org/search.php?allergensource=crab\&searchsource=Search. [1 Agustus 2014].

[10] European Directorate for the Quality of Medicines (EDQM). Monograph: Allergen Products - Producta Allergenica 01/2010:1063, In: Council of Europe (ed.) European Pharmacopoeia, 6, 2010, 679-680.

[11] K. Hashimoto, S. Watabe, M. Kono, K. Shiro. Muscle protein composition of sardine and mackerel, $B$ Jpn Soc Sci Fish 45(11), 1979, 1435-1441.

[12] F.R. Zakaria, A. Khatib, Ispurwanto, A. Rahman. Telaah sifat alergenisitas udang putih (Penaeus marguensis) untuk produksi isolat alergen, Bul Teknol dan Industri Pangan, 9, 1998, 54-59.

[13] U.K. Laemmli. Cleavage of structural proteins during the assembly of the head of bacteriophage T4, Nature, 227(5259), 1970, 680-5.

[14] D.M. Bollag, S.J. Edelstein, Protein Method (New York: Willey-Liss, 1991).

[15] R. Kumar, D. Kumari, P. Srivastava, V. Khare, H. Fakhr, N. Arora, S.N. Gaur, B.P. Singh. Identification of ige-mediated food allergy and allergens in older children and adults with asthma and allergic rhinitis, Indian J Chest Dis Allied Sci 52, 2010, 217-224.

[16] S.J. Maleki, A.M. Casillas, U. Kaza, B.A. Wilson, J.B. Nesbit, C. Reimoneqnue, H. Cheng, S.L. Bahna. Differences among heat-treated, raw, and commercial peanut extracts by skin testing and immunoblotting, Ann. Allergy Asthma Immunol, 105(6), 2010, 451-457.

[17] H. Miyazawa, H. Fukamachi, Y. Inagaki. Identification of the First Major Allergen of a squid (Todarodes Pacificus), J Allergy Clin Immunol, 98(5), 1996, 948-953.

[18] N.F. Adkinson, B.S. Bochner, W.W. Busse, S.T. Holgate, R.F. Lemanske, E.R. Simons, Middleton's Allergy: Principles and Practice (China: Mosby Elsevier, 2008).

[19] Z.H.M. Yadzir, R. Misnan, S. Murad. Identification of tropomyosin as major allergen of white squid (Loligo edulis) by two-dimensional immunoblotting and mass spectrometry, Southeast Asian J Trop Med Public Health, 43(1), 2010, 185-91.

[20] K. Shiomi, Y. Sato, S. Hamamoto, H. Mita, K. Shimakura. Sarcoplasmic calcium-binding protein: identification as a new allergen of the black tiger shrimp penaeus monodon, Int Arch Allergy Immunol, 146(2), 2008, 91-8.

[21] A. Morikawa, M. Kato, K. Tokuyama, T. Kuroume, M. Minoshima, S. Iwata. Anaphylaxis to grand keyhole limpet (abalone-like shellfish) and abalone, Annals of allergy, 65(5), 1990, 415-417.

[22] H.L. Yu, W.W. Ruan, M.J. Cao, Q.F. Cai, H.W. Shen, G.M. Liu. Identification of physicochemical properties of Scylla paramamosain allergen, arginin kinase, J Sci Food Agric, 93(2), 2013, 245-253.

[23] J. Azofra, M. Lombardero. Limpet anaphylaxis: cross-reactivity between limpet and house-dust mite Dermatophagoides pteronyssinus, Allergy, 58(2), 2003, 146-149. 